\title{
Transglobal comparisons of nuclear and mitochondrial genetic structure in a marine polyploid clam (Lasaea, Lasaeidae)
}

\author{
DEREK J. TAYLOR* $†$ \& DIARMAID Ó FOIGHIL \\ $\dagger$ Department of Biological Sciences, SUNY at Buffalo, Buffalo, New York, 14260, U.S.A. and $\ddagger$ Museum of Zoology \\ and Department of Biology, University of Michigan, Ann Arbor, Michigan 48109-1079, U.S.A.
}

\begin{abstract}
Existing genetic studies have proposed that the intertidal clam, Lasaea, is one of a few animal groups with asexual lineages that has persisted for an evolutionarily significant time. This proposal is based on the exceptional mitochondrial genetic divergence between studied sexual and asexual lineages. Nevertheless, a conclusion of long-lived asexuality awaits a more comprehensive sampling of the collective global range of this taxon. We assessed the breeding system and phylogeography of geographically divergent Lasaea populations using nuclear and mtDNA genetic markers. The allozyme genetic structure of five populations (from Japan, New Zealand, South Africa, Florida and Bermuda) showed marked deviation from expected random mating patterns (within and among loci), frequent fixed heterozygosity, and reduced genotypic diversity. This pattern and the finding of multiple asymmetric allozymic heterozygotes, indicated a clonal structure consistent with allopolyploid origins for each population. Spatial analysis of mtDNA and allozyme markers revealed strong geographical structure and yielded no cosmopolitan clonal lineages. Australian sexual species formed sister taxa to a minority of the clonal lineages, but pronounced mitochondrial genetic divergence levels and developmental differences precluded their identification as convincing parental species to any of the clones. A majority of asexual lineages may have originated in areas where no sexual congeners are presently known. The observed nuclear and mtDNA genetic structure is consistent with Lasaea clonal diversity being enriched by local mutational derivatives but infrequent recombination cannot be ruled out.
\end{abstract}

Keywords: allozymes, asexual, clam, Lasaea, mitochondrial DNA, polyploid.

\section{Introduction}

Considerable theoretical interest in the maintenance of sexual reproduction has fuelled recent empirical evolutionary studies of taxa that possess sexual and asexual members (Kondrashov, 1993). These studies have yielded valuable insights into the origins, genotypic diversity, and evolutionary persistence of asexual lineages. Most of the studied metazoan asexual taxa are polyploid hybrids (Moritz et al., 1992; Vrijenhoek, 1994). Estimated ages of asexual taxa have usually been based on mitochondrial genome divergence levels from sexual congeners. Studies of vertebrate asexual taxa typically yielded mtDNA divergence values of $<1 \%$, indicating that these clonal lineages were recently derived (reviewed by Avise, 1994). These empirical data are largely congruent with theoretical expectations that

\footnotetext{
*Correspondence. E-mail: djtaylor@acsu.buffalo.edu
}

(C) 2000 The Genetical Society of Great Britain. asexual lineages are extinguished rapidly (Lynch \& Gabriel, 1990; Kondrashov, 1993), and that extant clones merely represent the terminal tips of major phylogenetic branches (Maynard Smith, 1986).

Nevertheless, the marine clam Lasaea is one of a few potential exceptions to the rapid extinction of asexual lineages (Judson \& Normark, 1996). This genus consists of minute ( $<6 \mathrm{~mm}$ length), hermaphroditic bivalves that live on rocky shores world-wide (Ó Foighil, 1989). Only two diploid sexual species are known, and both are apparently Australian endemics (Ó Foighil, 1988; Tyler-Walters \& Crisp, 1989; Ó Foighil \& ThiriotQuiévreux, 1999). Cytogenetic studies have revealed that Lasaea populations from a variety of global locations (i.e. Australia, Europe, the north-eastern Pacific and Kerguelen Island) are composed of polyploid clonal lineages, many of which display supernumerary chromosomes (Thiriot-Quiévreux et al., 1988; Ó Foighil \& Thiriot-Quiévreux, 1991, 1999). Moreover, clones 
typically show fixed heterozygosity at multiple allozyme loci, and these Mendelian markers failed to segregate in their progeny (Crisp et al., 1983; Crisp \& Standen, 1988; Ó Foighil \& Eernisse, 1988; TylerWalters \& Crisp, 1989; but see the RAPD evidence of Tyler-Walters \& Hawkins, 1995). Intensive karyological studies have so far failed to find meiotic metaphases in this polyploid grouping (Thiriot-Quiévreux et al., 1988; Ó Foighil \& Thiriot-Quiévreux, 1991, 1999) and, at least in north-eastern Pacific clones, eggs are activated gynogenetically by autosperm (Ó Foighil \& ThiriotQuiévreux, 1991).

Recently, Ó Foighil \& Smith $(1995,1996)$ reconstructed the phylogenetic relationships of reproductively characterized Lasaea populations using Cytochrome Oxidase III (CO III) mitochondrial gene sequences. A robust dichotomy was evident in all phylogenetic trees, and each of the two main clades included a diploid sexual Australian taxon. Nevertheless, the authors found an exceptionally high degree of genetic divergence between asexuals and putative sexual ancestors. A minimum mitochondrial genetic divergence value of $16 \%$ was recorded for sympatric Australian sexual-asexual pairs, which yields an estimated divergence time of 6-7 Myr (Ó Foighil \& Smith, 1995). Because of the large genetic divergences among sexual and asexual lineages, neither sexual congener could be identified as a parental species to the asexual lineages, and Ó Foighil \& Smith (1995) concluded that asexual Lasaea were polyphyletic with mitochondrial contributions from at least two unknown parental species.

Known sexual diploid species of the genus Lasaea are restricted to Australia and Ó Foighil \& Smith (1995) proposed that Australia may represent a centre of origin for asexual polyploid taxa. Nevertheless, sexual parental species could be prevalent in unstudied portions of the large range of this genus. One of our goals was to assess breeding system variation in five unexamined geographically disparate populations from Japan, New Zealand, South Africa, Florida and Bermuda with multiple nuclear markers. A second goal was to infer a phylogeography and test the hypothesis of cosmopolitanism for lineages of Lasaea. Our nuclear and mtDNA results show that the newly examined populations have a clonal polyploid genetic structure, but that these multilocus clones and mtDNA haplotypes are locally distributed.

\section{Materials and methods}

\section{Collection of specimens}

Specimens of Lasaea were sampled from rocky shore intertidal crevice microsites at five global locations (Fig. 1). Collections were taken in: August 1995 from among the byssal threads of the mussel Septifer virgatus at the Nagasaki University Marine Laboratory foreshore, Nomo Saki, Nagasaki, Japan; January 1996 from among tubes of the vermetid gastropod Dendropoma corallinacea in the mid-low intertidal at Gonubie, Eastern Cape Province, Republic of South Africa; April 1996 from among high intertidal barnacles and vermetid gastropods in Phil Foster Park, West Palm Beach, Florida, U.S.A; May 1996 from among the byssal threads of the mussel Brachidontes domingensis at Flatts Inlet bridge, Bermuda; and September 1996 from high intertidal rock crevices at Lyall Bay, Wellington, New

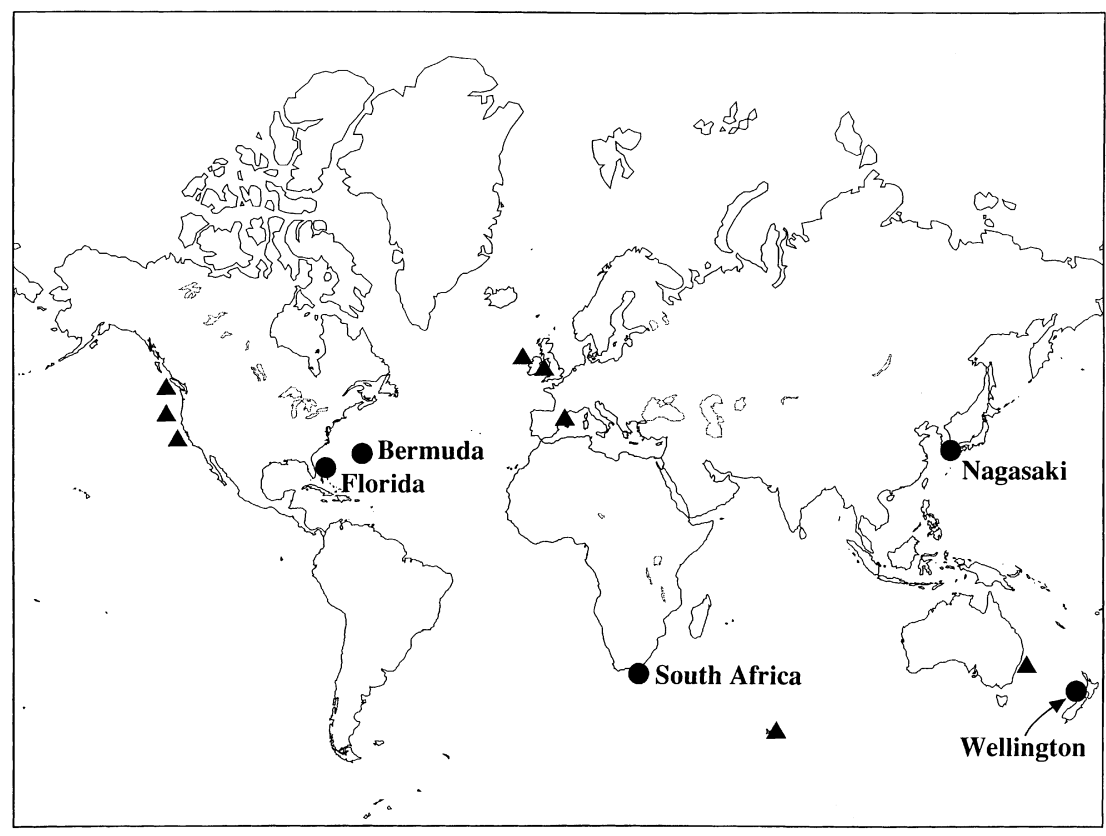

Fig. 1 Global map showing locations of previously characterized Lasaea populations (solid triangles, see text for references) and of present study populations (solid circles).

(C) The Genetical Society of Great Britain, Heredity, 84, 321-330. 
Zealand. These specimens were transported live to Ann Arbor, Michigan where they were stored at $-70^{\circ} \mathrm{C}$ until processed.

\section{Allozymes}

Electrophoresis was carried out for runs of $30-45 \mathrm{~min}$ on cellulose acetate gels according to the methods of Hebert \& Beaton (1993). Individuals from each population were ground in buffer $(25 \mathrm{~mm}$ Tris- $190 \mathrm{~mm}$ glycine, $\mathrm{pH} 8.5$ ) and $4-5 \mu \mathrm{L}$ of the resulting homogenate were added to application plate wells. Homogenate from an Australian population of the sexual species Lasaea australis (Lamarck 1818) was used as a standard on each gel. Electromorphs from different populations were also compared side-by-side on gels for variable loci. Enzyme systems assayed were: aldehyde oxidase (Ao, EC 1.2.3.1), arginine kinase (Ark, EC 2.7.3.3), aspartate aminotransferase (Aat, EC 2.6.1.1), mannose-6-phosphate isomerase (Mpi, EC 5.3.1.8), fumarate hydratase (Fumh, EC 4.2.1.2), malate dehydrogenase (Mdh, EC 1.1.1.37), malate dehydrogenase (NADP + , Mdhp, EC 1.1.1.40), isocitrate dehydrogenase (Idh, EC 1.1.1.42), phosphoglucomutase (Pgm, EC 5.4.2.2), phosphogluconate dehydrogenase (Pgdh, EC 1.1.1.44) and glucose-6phosphate isomerase (Gpi, EC 5.3.1.9). All enzyme systems appeared polymorphic in the initial assays, but only Ark, Gpi, Pgdh, Mdh and Pgm showed consistent resolution with the tris-glycine buffer system. Alleles were assigned numerals that ascended with anodal mobility.

Analysis of allozyme variation was carried out using BIOSYs-1 (Swofford \& Selander, 1981). Genotypic frequencies for each population were tested for agreement with Hardy-Weinberg expectations and nonrandom dilocus associations using Fisher's exact test. A pairwise genetic distance matrix (Chord distance; Cavalli-Sforza \& Edwards, 1967) was calculated and exposed to multidimensional scaling (MDS) to explore multilocus genotype relations. This distance measure is less affected by within-taxon heterozygosities than other standard distance measures (Swofford et al., 1996). We used MDS as a graphical tool to explore spatial genetic relations from allozymes because this approach does not force intermediate groups (expected from hybridization or clines) into nonintermediate positions as in a tree (Lessa, 1990).

\section{Mitochondrial gene sequences}

At least five representatives from each of the four study populations (including the main genotypes detected by allozyme characterization), were sequenced for mitochondrial DNA variation. Bermudian specimens were not included because previous mitochondrial characterization, using large ribosomal subunit sequences, had revealed them to be minor haplotypic variants of the Floridian study population (Ó Foighil \& Jozefowitz, unpubl. obs.). Mitochondrial DNA templates were extracted for thermal cycle amplification and direct sequencing of a 624-nucleotide fragment of Cytochrome Oxidase III (CO III) as described previously (Ó Foighil $\&$ Smith, 1995). Double-stranded products were isolated on $1 \%$ agarose gels, excised under long wavelength UV light $(365 \mathrm{~nm})$ and agarose-gel purified. Both strands of the amplified fragments were directly cycle-sequenced using the original amplification primers and electrophoresed on an ABI 377 automated DNA sequencer. Translations to inferred amino acid sequences were performed using the Drosophila yakuba mitochondrial genetic code. Once aligned, sequences were analysed with a maximum parsimony (PAUP 3.1) criterion and heuristic search algorithm with 20 stepwise random additions of taxa (Swofford, 1993). Kellia suborbicularis was designated as an outgroup. Branch support levels were estimated with nonparametric bootstrapping (500 replicates), and decay index values calculated using TREEROT (Sorenson, 1996).

\section{Results}

\section{Allozymes}

Banding patterns were consistent with predicted quaternary structure and number of isozymes, which are well known and conserved among most animals (Hebert $\&$ Beaton, 1993). For example the enzyme system $\mathrm{MDH}$ typically has two isozymes, a cytosolic and a mitochondrial zone, both of which are dimers. We observed the expected two zones with three equally-spaced bands in heterozygotes for Lasaea (Fig. 2). Likewise, the other

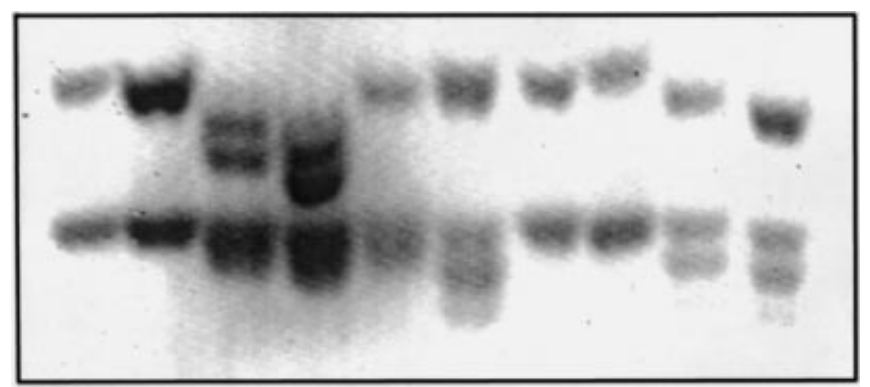

Fig. 2 Cellulose acetate gel showing $M d h$ electromorphs obtained for 10 Lasaea specimens comprising two individuals from five separate populations. Lanes 1-2, Australian standards; lanes 3-4, Florida; lanes 5-6, New Zealand; lanes 7-8, Japan; lanes 9-10, South Africa. 
scored loci showed expected band numbers and spacing (Fig. 3). The band intensities, however, were unconventional for diploids, as all six of the scored loci had individual electromorphs with unbalanced band intensities (Fig. 2, Table 1). The unbalancing was consistent among runs, showed multilocus associations (Table 1), and involved several different alleles, indicating that these observations are unlikely to result from to electrophoresis artifacts. For the genetic distance and disequilibrium calculations, we treated asymmetric diallelic heterozygotes the same as symmetric diallelic heterozygotes.

A summary of the allozyme variation found in Lasaea is presented in Table $1 . M d h-2$ had only two detected alleles, whereas the remaining five loci had five to eight alleles. A total of 28 multilocus genotypes was detected with the population ranges being three (Japan) to eight (New Zealand). New Zealand differed from the other populations in having a more even genotypic diversity; other sites had common and rare genotypes (Fig. 4). Overall, a high level of polymorphism and heterozygosity (Table 2) characterizes the populations.

Both within- and among-locus genotypic variation were markedly different from expected patterns with random mating. Eighteen of 22 comparisons of polymorphic loci showed pronounced and significant heterozygote excesses from Hardy-Weinberg expectations (Table 3). Still, two of these polymorphic loci (Gpi and Pgm-1) in the Japanese samples showed significant heterozygote deficiencies as indicated by the positive fixation index coefficient. Nearly all dilocus comparisons revealed nonrandom associations or linkage disequilibrium (Table 3).

Multidimensional scaling of the genetic distances among multilocus clones revealed clear geographical

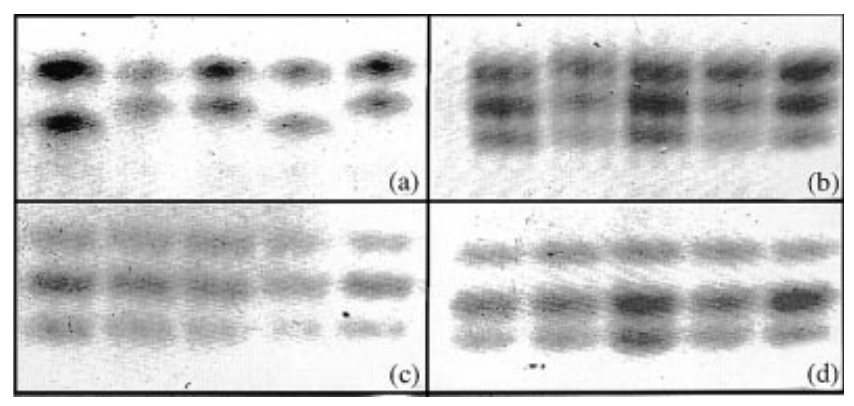

Fig. 3 Fixed heterozygous electromorphs obtained from five South African Lasaea individuals for four enzymes: (a) Ark (monomer exhibiting two clonal patterns); (b) Gpi (dimer);

(c) Pgdh (dimer); (d) Pgm-1 (monomer; Pgm-2, a well-known isozyme, is the third zone). South African specimens also displayed a heterozygous phenotype for one of the two $M d h$ loci (see Fig. 2). structure (Fig. 4). No genotype was shared among sites, and with the exception of the Japanese site, genotypes from a given site formed a discrete group. This pattern indicates that genotypes at a given site are usually more closely related to one another than to those at other sites. One factor contributing to this pattern is that some genotypes within a site differed only by the unbalancing of the alleles.

\section{Mitochondrial gene sequences}

Figure 5 shows the aligned nucleotides for the $624 \mathrm{nt}$. of CO III determined for all of these individuals. A total of 12 mitochondrial genotypes were detected among the 20 Lasaea specimens sequenced from four global populations. Four haplotypes occurred in both the New Zealand and Japanese subsamples, three in the South African subsample and a single mitochondrial genotype was encountered in the Floridian subsample. A total of 226 positions were variable (44, 22 and 160, respectively, for 1st, 2nd and 3rd codon positions) and a Kimura two-parameter distance matrix is presented in Table 4 for the main mitochondrial genotypes.

Prior to phylogenetic analyses, the CO III sequences were amalgamated with homologous data from previously characterized Lasaea populations and with an outgroup taxon, Kellia laperousi (Ó Foighil \& Smith, 1995). Parsimony analyses consistently resolved the combined data set into three equally most parsimonious trees of 898 steps $(\mathrm{CI}=0.492 ; \mathrm{RI}=0.508)$ that differed only in the relative placement of the Japanese haplotypes JPN1-3 in the terminal tips of the trees. A strict consensus tree is presented in Fig. 6. The pronounced mitochondrial dichotomy detected in this genus by Ó Foighil \& Smith (1995) was robustly reinforced by the incorporation of the novel sequences. Two of the novel genotypes (JPN4, Florida) coclustered with an Australian clonal lineage (LRAUSDD) within the clade containing L. australis, one of the two Australian diploid sexual species. All of the additional novel mitochondrial genotypes were positioned in the other mitochondrial clade basal to L. colmani, the second sexual diploid Australian species. Japanese haplotypes JPN1-3 were basal to all other genotypes in the L. colmani clade and the South African and New Zealand genotypes formed a non-Australian Southern Hemisphere subclade together with Kerguelen Island (KERG) sub-Antarctic congeners (Fig. 6). New Zealand individuals exhibited significant intrapopulational genetic divergence levels and some of these haplotypes (NZ1, NZ2) robustly coclustered with Kerguelen Island congeners. As with the allozyme variation, a striking degree of intrapopulational genetic divergence was present in the Japanese subsample that encompassed 
Table 1 Multilocus genotype frequencies from six allozyme loci in transglobal populations of the marine clam Lasaea

\begin{tabular}{|c|c|c|c|c|c|c|c|}
\hline \multirow[b]{2}{*}{ Site } & \multirow[b]{2}{*}{$N$ (freq.) } & \multicolumn{6}{|c|}{ Multilocus genotypes } \\
\hline & & Ark & $P g d h$ & Gpi & $M d h-1$ & $M d h-2$ & Pgm-1 \\
\hline Bermuda & $15(0.500)$ & 46 & 55 & 45 & 55 & 22 & 56 \\
\hline Bermuda & $5(0.167)$ & 46 & 55 & $35^{*}$ & 55 & 22 & 56 \\
\hline Bermuda & $5(0.167)$ & 46 & 55 & 35 & 55 & 22 & 56 \\
\hline Bermuda & $2(0.067)$ & 46 & 55 & 35 & 55 & 12 & 56 \\
\hline Bermuda & $2(0.067)$ & 46 & 55 & 45 & 55 & 12 & 56 \\
\hline Bermuda & $1(0.034)$ & 46 & 55 & $3 * 5$ & 55 & 22 & 56 \\
\hline Florida & $22(0.815)$ & 46 & 55 & 55 & $45^{*}$ & $1 * 2$ & 56 \\
\hline Florida & $2(0.074)$ & 46 & 55 & 55 & $45^{*}$ & $12^{*}$ & 56 \\
\hline Florida & $2(0.074)$ & 46 & 55 & 55 & 55 & $1 * 2$ & 56 \\
\hline Florida & $1(0.037)$ & 46 & 55 & 55 & $45^{*}$ & $1 * 2$ & $5 * 6$ \\
\hline Japan & $29(0.784)$ & $3 * 7$ & $2 * 4$ & 88 & 55 & 22 & 11 \\
\hline Japan & $7(0.189)$ & $35^{*}$ & 77 & 44 & 55 & 22 & 33 \\
\hline Japan & $1(0.027)$ & $35^{*}$ & 77 & 35 & 55 & 22 & 33 \\
\hline New Zealand & $8(0.211)$ & 27 & 25 & 56 & 35 & 22 & 34 \\
\hline New Zealand & $7(0.184)$ & 16 & 11 & 18 & 55 & 22 & 34 \\
\hline New Zealand & $6(0.158)$ & 27 & 36 & 56 & 35 & 22 & 34 \\
\hline New Zealand & $5(0.132)$ & 27 & 36 & 36 & 35 & 22 & 34 \\
\hline New Zealand & $5(0.132)$ & 27 & 36 & $37 *$ & 25 & 22 & 34 \\
\hline New Zealand & $2(0.053)$ & 27 & 25 & 36 & 35 & 22 & 34 \\
\hline New Zealand & $2(0.053)$ & 27 & 25 & 36 & 15 & 22 & 34 \\
\hline New Zealand & $2(0.053)$ & 27 & 23 & 56 & 35 & 22 & 34 \\
\hline New Zealand & $1(0.026)$ & 27 & 36 & 36 & 15 & 22 & 34 \\
\hline S. Africa & $17(0.515)$ & 35 & 37 & 37 & $25^{*}$ & 22 & 35 \\
\hline S. Africa & $12(0.364)$ & 37 & 37 & 37 & $25^{*}$ & 22 & 35 \\
\hline S. Africa & $1(0.030)$ & 37 & 37 & $37^{*}$ & $25^{*}$ & 22 & 35 \\
\hline S. Africa & $1(0.030)$ & 37 & 37 & 37 & $25^{*}$ & 22 & 55 \\
\hline S. Africa & $1(0.030)$ & 37 & 37 & 27 & $25^{*}$ & 22 & 35 \\
\hline S. Africa & $1(0.030)$ & 35 & 37 & 37 & $25^{*}$ & 22 & $25^{*}$ \\
\hline
\end{tabular}

* Unbalanced alleles showing greater intensity than expected from diploids.

both major Lasaea mitochondrial clades. Haplotype JPN4 individuals, present in the L. australis mitochondrial clade, exhibited the $G p i^{44}$ allozyme phenotype $(N=4)$ whereas haplotypes JPN1-3, positioned in the L. colmani mitochondrial clade, expressed the $G p i^{88}$ clonal electromorph $(N=6)$.

\section{Discussion}

\section{Genetic structure and reproductive modes}

Our allozyme evidence clearly supports the hypothesis that asexual, polyploid Lasaea prevail over diploid sexual taxa in this globally distributed complex. The nuclear genetic structure differs from the sexual Lasaea in having profound deviations from random mating expectations (both within and among loci), prevalence of fixed heterozygosity, presence of unbalanced electromorphs at multiple loci and the dominance of populations by one or two apparent multilocus genotypes despite marked allelic diversity. Although this genetic architecture differs from that observed with sexual recruitment in Lasaea (Ó Foighil, 1988; Tyler-Walters \& Crisp, 1989), such a pattern is expected of a parthenogenetic, allopolyploid complex. Prior studies have reported that Lasaea with clonal allozyme structure also have nonrecombinant offspring and diminished investment in male gonad tissue, supporting the hypothesis of parthenogenesis. We have doubled the geographical regions analysed from previous allozyme efforts (Mediterranean, north-east Atlantic, north-east Pacific and Australia), and convincing sexual populations still remain undetected outside Australia. Resolution of the cause of clonality in the Lasaea populations studied here needs further work, because such a pattern can be caused by either apomixis or obligate selfing (Avise, 1994). Both processes have been proposed in this genus (Tyler-Walters \& Hawkins, 1995).

The finding of unbalanced diallelic electromorphs at every locus scored is a new, but expected, finding for 


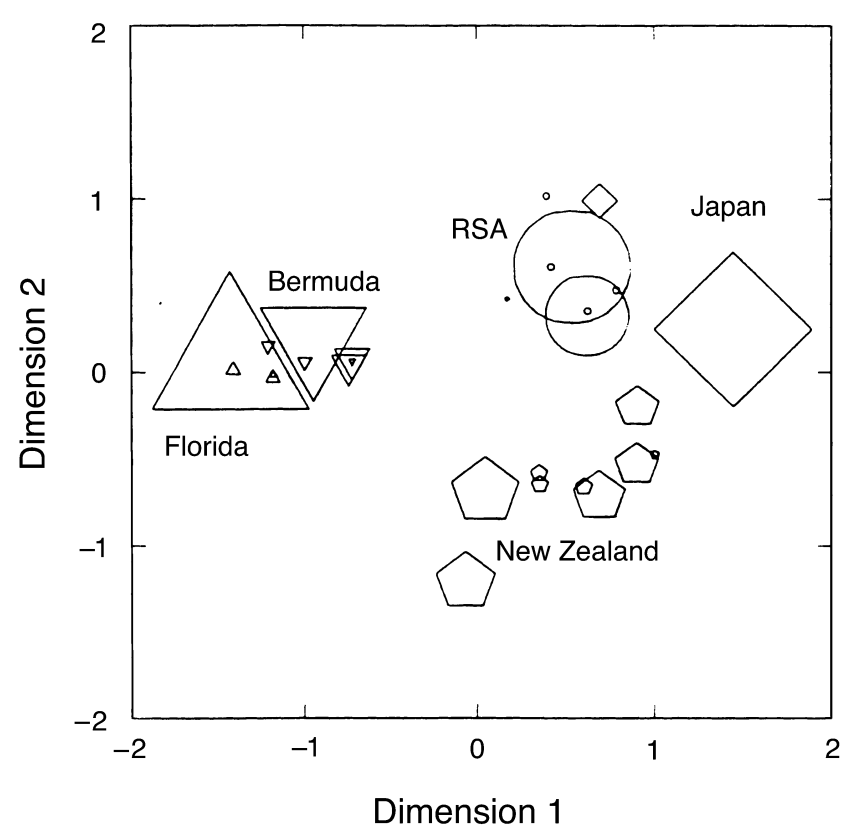

Fig. 4 Multidimensional scaling of a genetic distance (Cavalli-Sforza and Edwards' chord) matrix derived from six allozyme loci. Each symbol represents a multilocus genotype or clone of Lasaea, labelled according to geographical site and sized according to its population frequency.

Table 2 Summary of genetic variation in populations of Lasaea based on six allozyme loci. Symbols represent the number of individuals $(N)$, the number of detected multilocus genotypes $(G)$, the proportion of polymorphic loci $(P$; where a polymorphic locus contains more than one allele), the number of alleles per locus $(A)$, the expected heterozygosity with random mating $\left(H_{\mathrm{e}}\right)$, and the observed direct count heterozygosity $\left(H_{\mathrm{o}}\right)$

\begin{tabular}{lcccccc}
\hline Site & $N$ & $G / N$ & $P$ & $A$ & $H_{\mathrm{e}}$ & $H_{\mathrm{o}}$ \\
\hline Bermuda & 30 & 0.20 & 0.83 & 1.83 & 0.296 & 0.648 \\
Florida & 27 & 0.15 & 0.67 & 1.67 & 0.339 & 0.522 \\
Japan & 37 & 0.08 & 0.67 & 2.33 & 0.324 & 0.302 \\
New Zealand & 38 & 0.24 & 0.67 & 3.67 & 0.553 & 0.772 \\
South Africa & 33 & 0.18 & 0.83 & 2.33 & 0.449 & 0.828 \\
\hline
\end{tabular}

Lasaea allozyme studies, because cytogenetic investigations have identified polyploid populations of Lasaea (Thiriot-Quiévreux et al., 1988; Ó Foighil \& ThiriotQuiévreux, 1991, 1999). Our use of cellulose acetate gel electrophoresis not only permitted more enzyme assays per individual, but it probably improved resolution of polyploid specimens compared to previous starch methods (see also Städler et al., 1995). Unbalanced electromorphs are commonly reported in polyploid investigations and often considered diagnostic of polyploidy (Danzmann \& Bogart, 1982; Weider et al., 1987;
Little \& Hebert, 1997). By contrast, they are rarely reported in diploid allozyme studies, but it is possible that differing $\mathrm{V}_{\max }$ for alleles may create such a pattern (Hebert \& Beaton, 1993). As this is a very rare phenomenon, and we observed unbalancing at all six loci with multiple alleles per locus, polyploidy is the most likely cause of the allozyme asymmetry in Lasaea. Moreover, cell flow cytometry estimates of mean genome size of individuals from each of the present study populations showed at least a fourfold increase in the genome size from diploid sexual individuals (Ó Foighil, unpubl. obs.). In asexual polyploids, unbalancing may be caused by odd ploidy levels, hybridization between a homozygote and a heterozygote, or allele silencing.

Allopolyploids often show fixed heterozygosity because hybridizing species usually have fixed differences at a given locus. Thus, in recent hybrids, allelic diversity mostly results from parental contributions. Our study further establishes that the genus Lasaea has a unique genetic structure even among allopolyploids. For example, the mean heterozygosity is exceptionally high (cf. Städler et al., 1995), usually above (0.5) per population, and among populations we failed to find a monomorphic locus. Because hybridizing taxa are generally closely related, the number of polymorphic loci in allopolyploid systems is usually much less than the $100 \%$ we observed.

\section{Phylogeography and origins of reproductive mode}

The present study, which represents the first joint analysis of nuclear and mtDNA markers from this genus, provides new insights into the distribution and source of the observed genetic variation in Lasaea. First, the allozyme and mtDNA evidence failed to identify any truly cosmopolitan clones. Closely related clones are found only in the same region for both the mtDNA and allozymes. Although phylogenetic analysis of distantly related groups with allozymes is generally highly susceptible to homoplasy, our results do show that, as with mtDNA, clones within a region are generally most closely related to one another (Fig. 4). Nevertheless, there are some cases where Lasaea populations display pronounced levels of intrapopulational mtDNA divergence, i.e. sympatric clonal lineages in Japanese, Australian and Irish samples contain representatives of both main mitochondrial clades (Fig. 5). This intriguing pattern may have resulted, in part, from independent colonization events by genetically differentiated clonal lineages, or from mitochondrial contributions by regional parental species that have subsequently become extinct. The pronounced geographical structure of clonal Lasaea, with respect to nuclear and mtDNA 
Table 3 Fixation indices for Lasaea populations at six allozyme loci. A negative coefficient indicates a heterozygote excess, whereas a positive coefficient indicates a heterozygote deficiency

\begin{tabular}{lcccccr}
\hline & \multicolumn{5}{c}{ Fixation Index $(F)$} \\
\cline { 2 - 7 } Site & Ark & Pgdh & $G p i$ & Mdh-1 & Mdh-2 & Pgm-1 \\
\hline Bermuda & $-1.000^{*}$ & $-0.606^{* \mathrm{ab}}$ & $\mathrm{m}$ & $\mathrm{m}^{\mathrm{a}}$ & $-0.071^{\mathrm{bc}}$ & $-1.000^{* \mathrm{c}}$ \\
Florida & $-1.000^{*}$ & $\mathrm{~m}$ & $\mathrm{~m}$ & $-0.800^{*}$ & $-1.000^{*}$ & $-1.000^{*}$ \\
Japan & $-0.710^{*}$ & $-0.213^{*}$ & $0.923^{*}$ & $\mathrm{~m}$ & $\mathrm{~m}$ & $1.000^{*}$ \\
New Zealand & $-0.538^{*}$ & -0.027 & $-0.285^{*}$ & $-0.478^{*}$ & $\mathrm{~m}$ & $-1.000^{*}$ \\
South Africa & $-0.600^{*}$ & $-1.000^{*}$ & $-0.943^{*}$ & $-1.000^{*}$ & $\mathrm{~m}$ & $-0.887^{*}$ \\
\hline
\end{tabular}

m, monomorphic.

* Loci showing significant deviations from Hardy-Weinberg expectations (was set to 0.01 to control family wise error rate with five multiple tests).

a,b,c Dilocus pairs where random associations were not rejected with Fisher's exact test $(P>0.05)$-all other dilocus pairs showed significant nonrandom associations.

Table 4 Pairwise number of sequence differences for the main CO III Lasaea haplotype encountered. All changes are presented below the diagonal, mean distances are shown above the diagonal

\begin{tabular}{lrcccccc}
\hline & 1 & 2 & 3 & 4 & 5 & 6 & 7 \\
\hline 1 Florida & - & 0.220 & 0.080 & 0.232 & 0.236 & 0.239 & 0.215 \\
2 JPN1 & 137 & - & 0.228 & 0.196 & 0.181 & 0.180 & 0.170 \\
3 JPN4 & 50 & 142 & - & 0.240 & 0.231 & 0.232 & 0.220 \\
4 NZ1 & 145 & 122 & 150 & - & 0.128 & 0.138 & 0.135 \\
5 NZ3 & 147 & 113 & 144 & 80 & - & 0.034 & 0.144 \\
6 NZ4 & 149 & 112 & 145 & 86 & 21 & - & 0.147 \\
7 SA1 & 134 & 106 & 137 & 84 & 90 & 92 & - \\
\hline
\end{tabular}

variation, is consistent with their direct mode of development. They lack a pelagic larval development that would impart great vagility. The result of no shared clones among sites and of marked geographical structure also falsifies the notion that Lasaea is widely distributed because of recent invasion or introductions.

Our finding of highly localized, genetically discrete groups disagrees with the hypothesis that Lasaea represents a cosmopolitan collection of ecophenotypes. Likewise, our evidence makes the 'out of Australia' biogeographical scenario for asexual Lasaea less likely. The two sexual diploid Australian species, L. colmani and L. australis, form respective sister taxa to some of the clonal lineages found in Europe (IR1, IR3, FRMED) and to some clones encountered in Japan/ Australia/Florida (JPN4, LRAUSDD, Florida). However, pronounced mitochondrial genetic divergence levels, and developmental differences, preclude their identification as convincing parental species (Ó Foighil \& Smith, 1995). Moreover, the basal position of the JPN4 haplotype, relative to the Australian and Floridian clonal lineages, implies that the common parental species was not Australian. Other South African, New Zealand and Japanese clones form clades basal to the sexual L. colmani. Because sexual Australian species have produced no apparent asexual derivatives (even the nearby New Zealand clones are basal), there is no evidence that the distantly related asexual clones from around the world originated there.

Without identified sexual ancestors, the source of most of the among-site genetic variation in this allopolyploid complex remains unknown. Nevertheless, there is some evidence that locally restricted clones arose by mutational derivation. We found that a site often has one or two common clones, and that these clones often have several rare, endemic relatives. Although relatedness was not estimated in prior allozyme studies of Lasaea, it is clear that this pattern also occurs in the north-eastern Pacific (Ó Foighil \& Eernisse, 1988) and in the north-eastern Atlantic (Tyler-Walters \& Crisp, 1989). Some of the rare clones we found differed from the common clones only by allele dosage. In addition, the only population-based mtDNA study of Lasaea (Ó Foighil \& Smith, 1996) found a similar pattern for haplotypes in the northeastern Pacific. The most parsimonious explanation for this pattern is that the local satellite clones are mutational derivatives of the major clones in an area. If mutational derivation is an important source of clonal diversity, then most new mutants in a population 

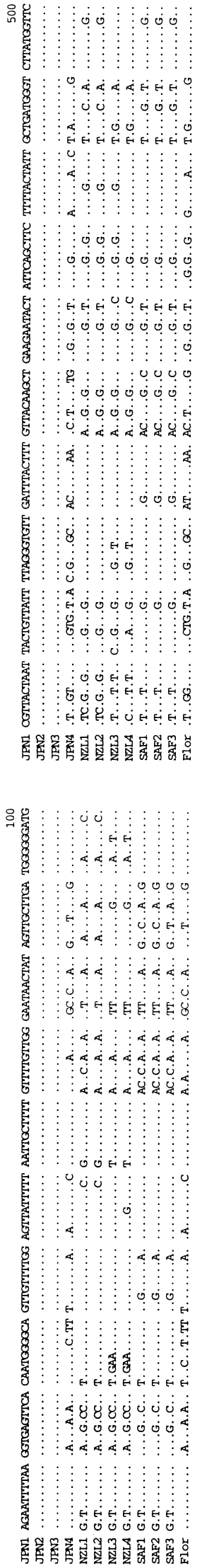
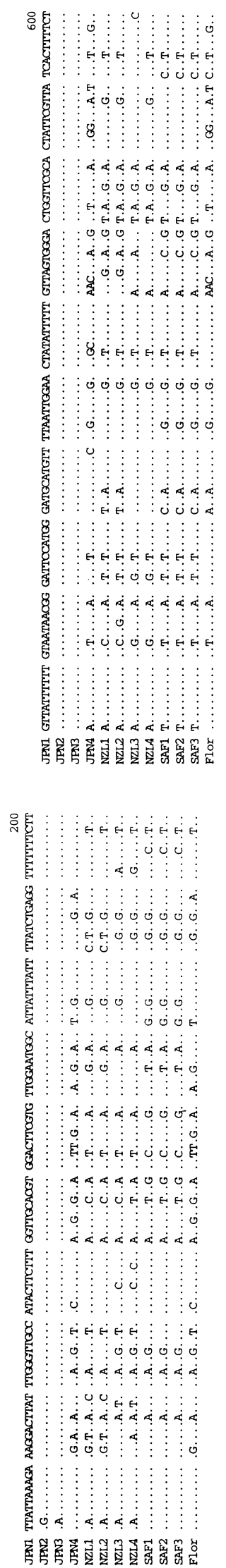
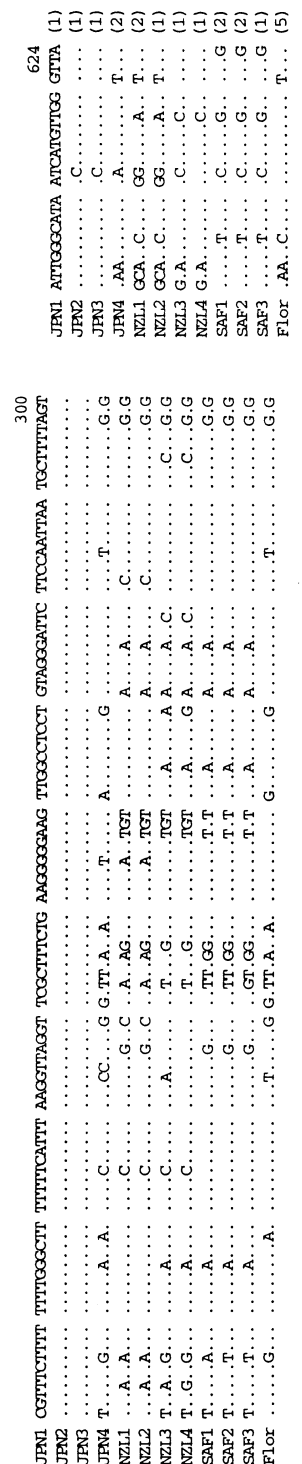

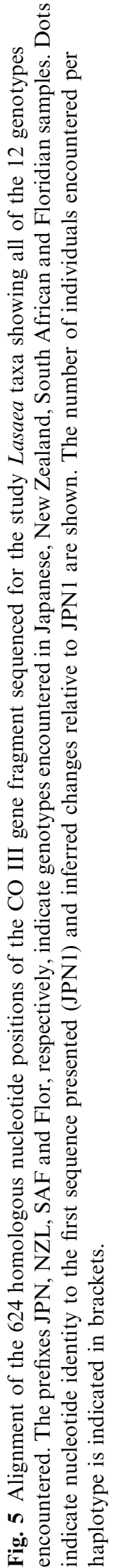

(c) The Genetical Society of Great Britain, Heredity, 84, 321-330. 


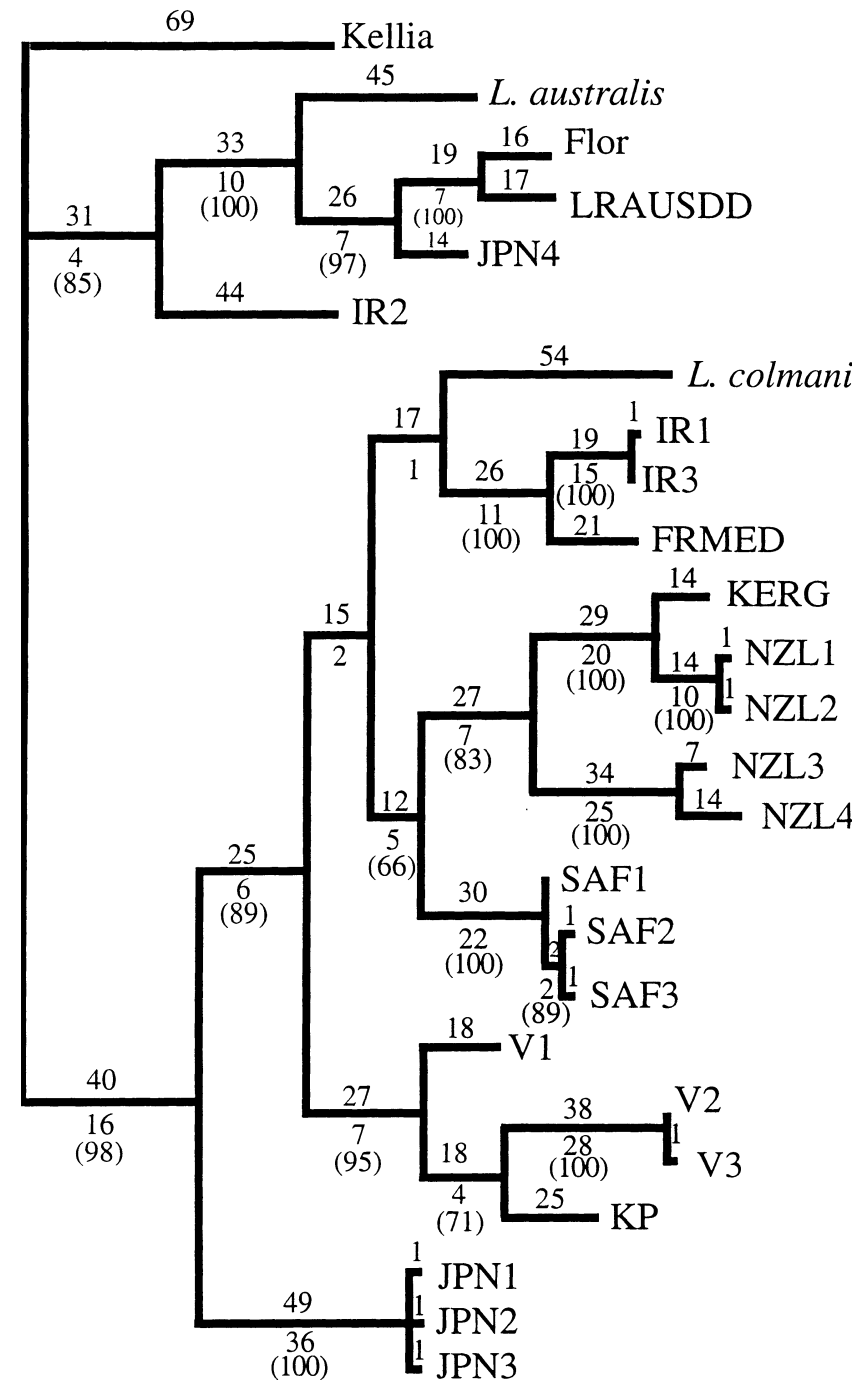

Fig. 6 Strict consensus of the two most parsimonious trees (898 steps) obtained by a heuristic search for optimal trees using the 12 Lasaea CO III genotypes presented in Fig. 5, together with a homologous data set from previously studied populations (Ó Foighil \& Smith, 1995). Kellia laperousi was employed as an outgroup and the two sexual diploid Australian species, L. australis and L. colmani, are in italics. The haplotype prefixes indicate the sampling origins of the clonal lineages: Flor (Florida), LRAUSDD (Australia), JPN (Japan), IR (Ireland), FRMED (French Mediterranean), SAF (South Africa), KERG (Kerguelen Island, southern Indian Ocean), V1-3 and KP (British Columbia, Canada). The two most parsimonious trees differed only in their relative positioning of the three terminal Japanese haplotypes (JPN1-3). The respective number of steps is indicated above each branch, and decay index values supporting each node are presented below the branches. Bootstrap values are shown in parentheses.

should be derived from the common clones, and a clonal phylogeny would resemble a star with each rare clone separated from the common clone by unique derived characters. If we examine the populations with this structure in our data (Bermuda, Florida, Japan and South Africa), 11 of the 12 rare clones $(<0.10)$ differ only by autapomorphies from a common clone. Inspection of the mtDNA data presented by Ó Foighil \& Smith (1996, Fig. 4b), reveals the same pattern: 12 of 15 rare clones are separated from common clones solely by a few unique derived characters, and there is almost no other phylogenetic structure to suggest that rare clones derive from other locations, hybridization events or uncommon clones.

Our allozyme and mtDNA phylogenetic characterization of globally distributed populations of this clam indicate that clonal polyploid lineages predominate outside Australia and that there is concordant geographical structuring for most lineages. The genus Lasaea shares its name with an ancient Cretan city whose ruins are still visible today. It is still unclear whether divergent lineages of the clam Lasaea are ancient genetic ruins or more recent constructs derived from cryptic or rare sexual lineages. Single-copy nuclear gene trees are presently being constructed for Lasaea that will directly test hypotheses of ancient allopolyploid origin and clonal persistence.

\section{Acknowledgements}

We are most grateful for the assistance of Tim Collins, Alan Hodgson, Hitoshi Kitamura, Bruce Marshall, Paula Mikkelsen, Tim Mousseau, Katherine Coates and Brenda Healy in obtaining samples for this study. Support was provided by a National Geographical Research Grant and NSF award 9617689 to D. O Foighil and by an NSERC postdoctoral fellowship to D. J. Taylor.

\section{References}

AVISE, J. C. 1994. Molecular Markers, Natural History and Evolution. Chapman and Hall, New York.

CAVAlli-SFORZA, L. L. AND EDWARDS, A. W. F. 1967. Phylogenetic analysis and estimation procedures. Evolution, 21, 550-570.

CRISP, D. J. AND STANDEN, A. 1988. Lasaea rubra (Montagu) (Bivalvia: Erycinea), an apomictic crevice-living bivalve with clones separated by tidal level preference. J. Exp. Mar. Biol. Ecol., 117, 27-45.

CRISP, D. J., BURFITT, A., RODRIGUES, K. AND BUDD, M. D. 1983. Lasaea rubra: an apomictic bivalve. Mar. Biol. Lett., 4, 127-136.

DANZMANN, R. G. AND BOGART, J. P. 1982. Gene dosage effects on $\mathrm{MDH}$ isozyme expression in diploid, triploid, and tetraploid treefrogs of the genus Hyla. J. Hered., 73, 277-280.

HEBERT, P. D. N. AND BEATON, M. J. 1993. Methodologies for Allozyme Analysis Using Cellulose Acetate Electrophoresis. Helena Laboratories, Beaumont, TX.

JUDSON, O. P. AND NORMARK, B. B. 1996. Ancient asexual scandals. Trends Ecol. Evol., 11, 41-46. 
KONDRASHOV, A. S. 1993. Classification of hypotheses on the advantage of amphimixis. Heredity, 84, 372-387.

LESSA, E. P. 1990. Multidimensional analysis of geographical genetic structure. Syst. Zool., 39, 242-252.

LitTle, T. AND heBert, P. D. N. 1997. Clonal diversity in high arctic ostracodes. J. Evol. Biol., 10, 233-252.

LYNCH, M. AND GABRIEL, W. 1990. Mutational load and the survival of small populations. Evolution, 44, 1725-1737.

MAYNARD SMITH, J. 1986. Contemplating life without sex. Nature, 324, 300-301.

MORITZ, C., WRIGHT, J. W. AND BROWN, W. M. 1992. Mitochondrial DNA analyses and the origin and relative age of parthenogenetic Cnemidophorus: phylogenetic constraints on hybrid origins. Evolution, 46, 184-192.

ó FOIGHIL, D. 1988. Random mating and planktotrophic larval development in the brooding hermaphroditic clam Lasaea australis. Veliger, 31, 214-221.

ó FOIGHIL, D. 1989. Planktotrophic larval development is associated with a restricted geographical range in Lasaea, a genus of brooding, hermaphroditic bivalves. Mar. Biol., 103, 349-358.

Ó FOIGHIL, D. AND EERNISSE, D. J. 1988. Geographically widespread, non-hybridizing, sympatric strains of the hermaphroditic brooding clam Lasaea in the northeastern Pacific Ocean. Biol. Bull., 175, 218-229.

Ó FOIGHIL, D. AND SMITH, M. J. 1995. Evolution of asexuality in the cosmopolitan marine clam Lasaea. Evolution, 49, $140-150$.

Ó FOIGHIL, D. AND SMITH, M. J. 1996. Phylogeography of an asexual marine clam complex, Lasaea, in the northeastern Pacific based on cytochrome oxidase III sequence variation. Mol. Phyl. Evol., 6, 134-142.

Ó FoIGHIL, D. AND THIRIOT-QuiÉvreuX, C. 1991. Ploidy and pronuclear interaction in northeastern Pacific Lasaea clones. Biol. Bull., 181, 222-231.

Ó FOIGHIL, D. AND THIRIOT-QUiÉvreuX, C. 1999. Sympatric Australian Lasaea species (Mollusca: Bivalvia) differ in their ploidy levels, reproductive modes and developmental modes. Zool. J. Linn. Soc., 127, 477-494.

SORENSON, M. D. 1996. Tree Rot. University of Michigan, Ann. Arbor.

STÄDLER, T., LOEW, M. AND STREIT, B. 1995. Genetics and mating systems of polyploid freshwater hermaphrodite snails. Malacol. Rev., 6 (Suppl.), 121-127.

SWOFFORD, D. L. 1993. PAUP: Phylogenetic Analysis Using Parsimony, version 3.1. Illinois Natural History Survey, Champaign, IL.

SWOFFORD, D. L. AND SELANDER, R. B. 1981. BIOSYS-1: a FORTRAN program for comprehensive analysis of electrophoretic data in population genetics and systematics. J. Hered., 72, 281-283.

SWOFFORD, D. L., OLSEN, G. J., WADDELl, P. J. AND HILLIS, D. M. 1996. Phylogenetic inference. In: Hillis, D. M., Moritz, C. and Mable, B. K. (eds) Molecular Systematics, pp. 407-514. Sinauer Associates, Sunderland, MA.

THIRIOT-QUIÉVREUX, C., SOYER, J., DE BOVÉE, F. AND ALBERT, P. 1988. Unusual chromosome complement in the brooding bivalve Lasaea consanguinea. Genetica, 76, 143-151.

TYLER-WALTERS, H. AND CRISP, D. J. 1989. The modes of reproduction in Lasaea rubra (Montagu) and L. australis (Lamarck): (Erycinidae; Bivalvia). In: Ryland, J. S. and Tyler, P. A. (eds) Proceedings of the 23rd European Marine Biological Symposium, Swansea, pp. 299-308. Olsen and Olsen, Denmark.

TYLER-WALTERS, H. AND HAWKINS, A. R. 1995. The application of RAPD markers to the study of the bivalve mollusc Lasaea rubra. J. Mar. Biol. Assoc., 75, 563-569.

VRIJENHOEK, R. C. 1994. Unisexual fish: model systems for studying ecology and evolution. Ann. Rev. Ecol. Syst., 25, 71-96.

WEIDER, L. J., BEATON, M. J. AND HEBERT, P. D. N. 1987. Clonal diversity in high arctic populations of Daphnia pulex, a polyploid, apomictic complex. Evolution, 41, 1335-1346. 